\title{
CALLIGYPONA OBSCURELLA (BOH.), A NEW VECTOR OF THE WHEAT STRIATE MOSAIC AND OAT STERILE-DWARF VIRUSES
}

\author{
KATRI IKÄHEIMO \\ Agricultural Research Centre, Department of Plant Pathology, \\ Tikkurila \\ and \\ Mikko RaAtikainen \\ Agricultural Research Centre, Department of Pest Investigation, \\ Tikkurila
}

According to the literature, three species of the leafhopper genus Calligypona (Hom., Araeopidae) are established to be vectors of plant viruses. C. marginata (F.) transmits oat pseudo-rosette (19), rice stripe (6) and rice black streaked stunt (16) viruses. C. furcifera (Horv.) is probably a vector of the aster yellows virus (1), though this has not been confirmed. C. pellucida (F.) transmits the wheat striate mosaic and oat sterile-dwarf viruses. This leafhopper transmits the wheat striate mosaic virus in many European countries, in England and Spain (18), in Czechoslovakia (13) and in Finland (3).

In the two latter countries $C$. pellucida acts as a vector of the oat sterile-dwarf virus, too $(12,4)$. This virus seems to be the main cause of the damage to oats occurring in western Finland (4). In Sweden also $C$. pellucida is found to transfer two virus diseases, oat striate and red disease and oat dwarf tillering disease, which are similar to wheat striate mosaic and oat sterile-dwarf, respectively $(8,9)$. The leafhopper Dicranotropis hamata (Boh.) is also able to act as a vector for oat dwarf tillering disease (10).

The wheat striate mosaic virus occurring in U.S.A. is transmitted by a cicadellid leafhopper, Endria inimica (Say) (17). This leafhopper does not occur in Europe (2).

In the course of tests on the food plants of $C$. obscurella, the latter author of this paper found that some plants showed symptoms closely resembling those caused by viruses. Therefore experiments were done to find out if this leafhopper, too, is a vector of the cereal viruses transmitted by $C$. pellucida. 


\section{Transmission of the wheat striate mosaic virus}

In 1958, leafhoppers of $C$. obscurella were collected from a barley field in the commune of Peräseinäjoki, in the biological province of Etelä-Pohjanmaa (EP). 22 long-winged males and 28 long-winged females were caged on altogether 103 Tammi oat plants at the three leaf stage on June 24, 1958. In July, some plants were diseased. The plants were examined on 1.9. On this date, 8 plants showed severe symptoms which were similar to those caused by the wheat striate mosaic transmitted by $C$. pellucida. The other plants in the cage seemed to be healthy.

Table 1. Virus transmissions by Calligypona obscurella.

Acquisition feed $\mathbf{9}$ days. 1 nymph per plant.

Control $=$ fed on healthy plants.

$+=$ plant infected

. = leafhopper died

$-=$ plant healthy

Transmission of the wheat striate mosaic virus.

Dates when leafhoppers were transferred to new plants

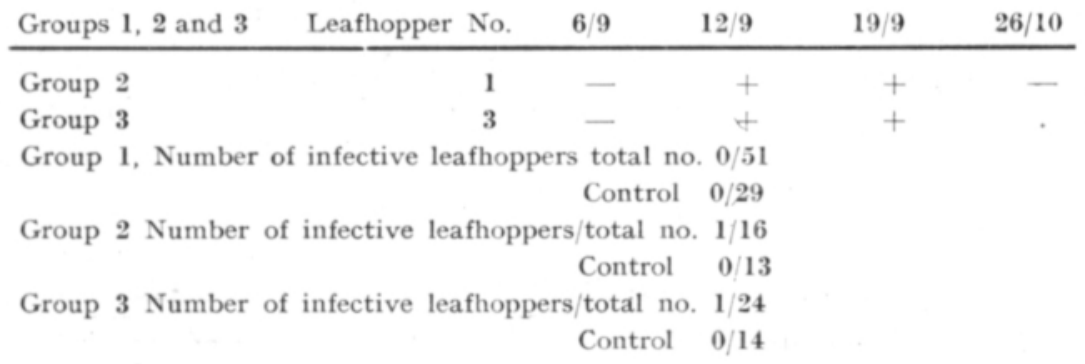

Transmission of the oat sterile-dwarf virus.

\begin{tabular}{|c|c|c|c|c|c|}
\hline Group 4 & Leafhopper No. & $13 / 9$ & $27 / 9$ & $3 / 10$ & $12 / 10$ \\
\hline & 2 ô & + & + & + & + \\
\hline & 4 우 & - & + & + & + \\
\hline & 6 우 & + & - & + & + \\
\hline & $7 q$ & + & + & + & + \\
\hline & 9 우 & - & + & + & . \\
\hline & $10 \nmid$ & + & - & + & \\
\hline
\end{tabular}

Number of infective leafhoppers/total no. 6/12

Control $0 / 5$

\begin{tabular}{rrrrrr} 
Group 5 & Leafhopper No. & $12 / 9$ & $28 / 9$ & $5 / 10$ & $12 / 10$ \\
\hline 1 & - & + & + & + \\
3 & - & + & - &. \\
12 & - & + & + &. \\
13 & + & + & + \\
16 & - & + & + \\
19 & - & + & +
\end{tabular}

Number of infective leafhoppers/total no. $6 / 24$ 
On June 17, 1960, C. obscurella adults were caught on the first year timothy grass leys in Laihia and Ylistaro, Etelä-Pohjanmaa (EP). The leafhoppers were caged in pairs in the glasshouse. They began to lay eggs some days after transfer to the glasshouse. The progeny of each pair was collected separately. The groups obtained in this way were used for virus transmission tests. Acquisition feed was given to nymphs at the II-IV stage on diseased winter wheat plants infected by C. pellucida. After the acquisition feed the leafhoppers were tested singly for several weeks on a succession of plants; other leafhoppers of these groups were tested at the same time to confirm that they were healthy, as shown in Table 1. Winter wheat was used as a test plant for the wheat striate mosaic virus.

None of the leafhoppers in the first group given acquisition feed transmitted the virus to the test plants. The second group consisted of 16 and the third group of 24 leafhoppers given acquisition feed. Only one leafhopper in each group transmitted the virus (Table 1). None of the control leafhappers were infective.

\section{Transmission of the oat sterile-dwarf virus}

Some of the leafhopper pairs, mentioned above, produced a disease in a succession of food plants. This disease closely resembled oat sterile-dwarf. The presumed non-infective progeny of pairs that had not infected their food plants were used in experiments on the transmission of the virus. Oats were also used as the test plant for the oat sterile-dwarf virus.

Two groups (No. 4 and 5) of half-grown nymphs were fed for 9 days on diseased plants infected by $C$. pellucida, and then tested singly on test plants as described above. The infective nymphs in group 4 numbered 6 out of 12 and 6 out of 24 in group 5. None of the control leafhappers were infective (Table 1).

C. obscurella acquired both viruses as a nymph and transmitted them as a nymph and as an adult. The oat sterile-dwarf virus was transmitted by both sexes of C. obscurella.

In the present experiments the wheat striate mosaic virus had a latent period of 10-24 days and the sterile-dwarf virus one of $10-33$ days. In our tests the latent periods of these viruses in $C$. pellucida have been 15-21 days and $7-37$ days, respectively $(3,4)$. Thus the incubation times of the striate mosaic and sterile-dwarf viruses seem to be similar in the two vectors.

The symptoms of these viruses appeared on the plants $3-5$ weeks after infection. The symptoms did not differ from those caused by wheat striate mosaic and oat sterile-dwarf transmitted by $C$. pellucida.

\section{C. obscurella and its life cycle}

C. obscurella differs from C. pellucida in the following features (Fig. 1): C. obscurella is smaller and darker; the proximal part of the costa and subcosta of the front wing is dark. The penis is twocleft and quite straight, whilst in C. pellucida it is strongly curved. 


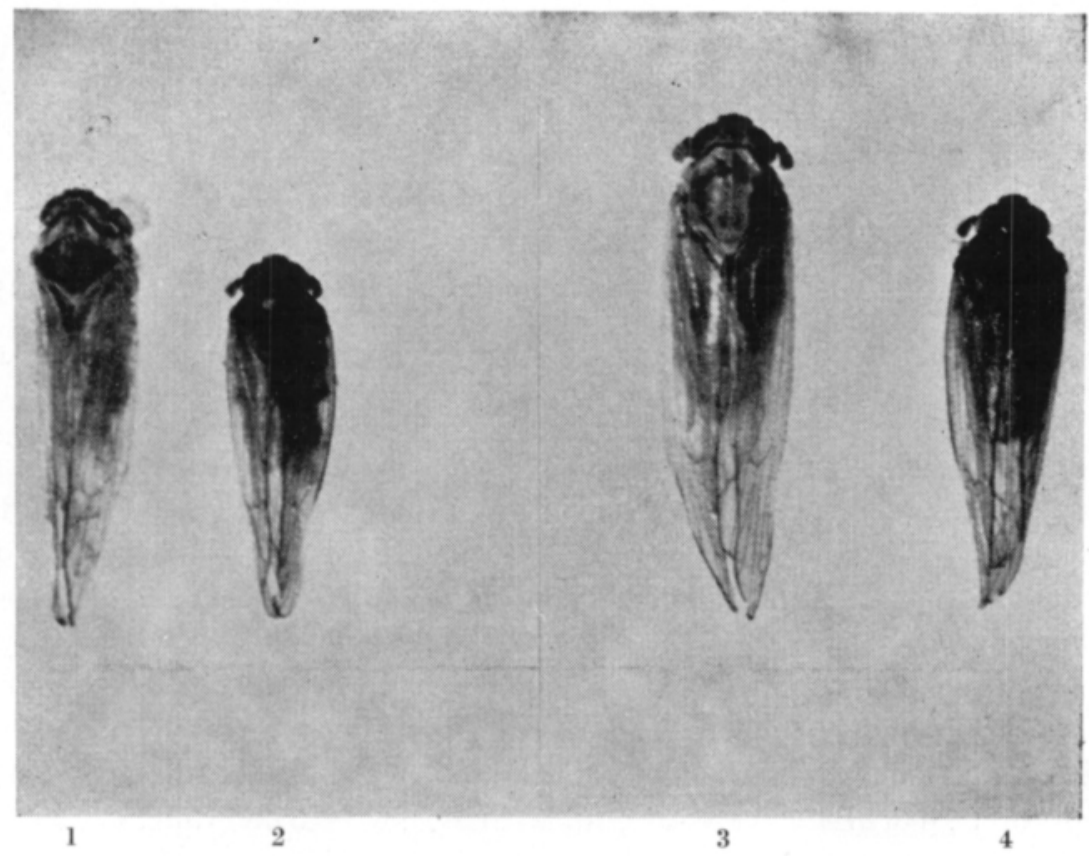

Fig. 1. C. pellucida male (No. 1), female (No. 3) and C. obscurella male (No. 2), female (No. 4). Magnification about $10 \times$.

C. obscurella is a circumpolar species found throughout Europe, Siberia and North America (cf. 11). In Finland, it occurs all over the country (7).

The life cycle of C. obscurella is similar to that of $C$. pellucida. C. obscurella produces one generation a year in Finland and hibernates at the nymphal stage. In Germany, in the district of Weser-Ems it has two generations a year but likewise hibernates at the nymphal stage (15).

In Finland, in the biological province of Etelä-Pohjanmaa (about $63^{\circ} \mathrm{N}$ and $22^{\circ} \mathrm{W}$ ), the main features of its life cycle are as follows: Oviposition begins in June. The eggs are usually laid in the stems and leaves of cereals, as in $C$. pellucida $(20,5)$. After the harvest, the nymphs feed on shoots remaining in the subble, on gramineous weeds and on the timothy grass established in the cereals.

The nymps seem to spend the winter in the habitats where they hatched, on the surface of the ground. Unless a grass is established in the cereals, the field is tilled in autumn or in spring and most of the nymphs of $C$. obscurella are destroyed. If a grass ley is sown, the nymphs survive.

Emergence starts in May or in some years possibly not until June. In 1959, for instance, the first adult was found on May 15, and in 1958 on June 8. Some of the adults are short-winged and some long-winged. Most specimens of $C . o b$ scurella occurring in grass leys and cereals in Etelä-Pohjanmaa are macropterous. From the end of May to the beginning of July the long-winged leafhoppers migrate from the grass leys, where they have overwintered, mainly to spring cereals and oviposit in these. 
According to the transmission tests $C$. obscurella seems to transmit the wheat striate mosaic and oat sterile-dwarf viruses like $C$. pellucida $(\mathrm{cf} .3,4)$. In the present experiments the proportion of individuals of $C$. obscurella which were able to transmit the oat sterile-dwarf virus was greater than of those able to transmit the wheat striate mosaic virus. Since different strains and individuals among the same leafhopper species vary greatly in their ability to transmit viruses, further experiments are needed to determine the ability of $C$. obscurella to act a virus vector.

In the biological province of Etelä-Pohjanmaa, $C$. obscurella seems to migrate to cereal fields somewhat earlier on the whole than $C$. pellucida. Being an early migratory species, it has at least as good an opportunity as $C$. pellucida to transmit viruses. C. obscurella is quite common in Finland, but it is usually considerably scarcer than $C$. pellucida. In 1959, the relative abundance of $C$. obscurella was only a small percentage of that of $C$. pellucida in the first year timothy grass leys in the biological provinces of $\mathrm{V}, \mathrm{St}, \mathrm{EP}$ and $\mathrm{KP}$ in the western coastal area. There seemed to be considerable local variation in its abundance, however. For instance, in a first-year grass ley in the commune of Kannus in Keski-Pohjanmaa (KP) 378 adult specimens of $C$. obscurella were caught with 60 sweeps on June 5,1959 . In this sample the percentage of $C$. obscurella of the $C$. pellucida group was 90 .

Locally and occasionally $C$. obscurella may perhaps be a noteworthy vector of cereal viruses. In 1956, however, when damage to oats amounted to as much as $50 \%$ in the communes of Sulva, Koivulahti, Laihia and Vähäkyrö in Etelä-Pohjanmaa, the part played by this species was negligible.

In the years 1956-1960, C. obscurella has been most abundant in Etelä-Pohjanmaa in those communes where damage to oats was slightest in 1956, whereas C. pellucida, the main distributor of the damage to oats (5), has reached its greatest abundance in the communes where the damage has been most severe (14).

\section{$S u m m$ ary}

By transmission tests $C$. obscurella was shown to transmit the wheat striate mosaic virus from wheat to wheat and the oat sterile-dwarf virus from oats to oats. In $C$. obscurella the incubation times of these viruses seem to be as long as in $C$. pellucida.

In its life cycle and distribution, $C$. obscurella closely resembles $C$. pellucida. In Finland the former is earlier but on the whole scarcer than $C$. pellucida. The ability of $C$. obscurella to transmit viruses seems to be similar to that of $C$. pellucida

Being scarcer, C. obscurella is obviously of less importance than $C$. pellucida as a vector of cereal viruses. Locally, it may, perhaps, be of some importance. 
(1) Fukoshi, 1930. Aster yellows in Japan. Agriculture \& Horticulture 5: 577-584, 1930 (Abs. in Japanese J. Botany 5: 31, 1930).

(2) HeINzE, K. 1959. Phytopathogene Viren und ihre Uberträger. Berlin. $290 \mathrm{~s}$.

(3) Ікӥнетмо, К. 1960. Two cereal virus diseases in Finland. J. Sci. Agric. Soc. Finland 32: 62-70.

(4) - - 1961. A virus disease of oats in Finland similar to oat sterile-dwarf. Ibid. 33: 81-87.

(5) Kanervo, V., Heikinheimo, O., Rantikainen, M. \& Tinnilä, A. 1957. The leafhopper Delphacodes pellucida (F.) (Hom., Auchenorrhynca) as the cause and distributor of the damage to oats in Finland. Publ. Finn. State Agric. Res. Board 160: 1-56.

(6) Kuribayashi, T. 1931. On the relation of Delphacodes striatellus Fall. to the transmission of the stripe disease of the rice plant. J. Plant. Prot. 18:565-571.

(7) Lindeberg, H. 1947. Verzeichnis der ostfennoskandischen Homoptera Cicadina. Fauna Fenn. 1: $1-81$.

(8) Lindsten, K. 1959. A preliminary report of virus diseases of cereals in Sweden. Phytopath. Z, 32: $420-428$.

(9) - $\quad$ 1961. Studies on virus diseases of cereals in Sweden I. On the etiology of a serious disease of oats (the "Bollnäs diseases). K. lantbr. högsk. Ann. 27: 137-197.

(10) - 1961. Studies on virus diseases of cereals in Sweden II. On virus diseases transmitted by the leafhopper, Calligypona pellucida (F.). Ibid. 27: 199-271.

(11) Metcalf, Z. P. 1943. General catalogue of the Hemiptera. IV, Fulgoroidea. 3, Araeopidae (Delphacidae). Smith College, Mass. U.S.A. 552 pp.

(12) PRŮ̌̌n, V., Jermoljev, E. \& VACKe, J. 1959. Oat sterile-dwarf virus disease. Biol. Plant. 1: $223-234$.

(13) PRŮ̌̌A, V. \& VACKE, J. 1960. Wheat striate virus. Ibid. 2: 276-286.

(14) Rantikainen, M. \& Tinnilä, A. 1959. Viljakaskaan (Calligypona pellucida F.) aiheuttaman kaurantuhon vaikutus kauran viljelyalaan ja satoihin Suomessa. Summary: The effect of the damage to oats caused by Calligypona pellucida $\mathrm{F}$. on the acreages and yields of oats in Finland. J. Scient. Agric. Soc. Finl. 31: 49-66.

(15) Remane, R. 1958. Die Besiedlung von Grünlandflächen verschiedener Herkunft durch Wanzen und Zikaden im Weser-Ems-Gebiet. Z. angew. Ent. 42: 353-400.

(16) Shinkai, A. 1954. Insect transmission of rice plant viruses. (English summary). Hatano Tobacco Expt. Sta. Symposium on transmission of Plant Viruses 4: 354-359.

(17) Styknuis, J. T. 1953. Striate mosaic, a new disease of wheat in South Dakota. Phytopathology 43: $537-540$.

(18) - - \& W Atson, M. A. 1958. Striate mosaic of cereals in Europe and its transmission by Delphacodes pellucida (Fabr.). Ann. appl. Biol. 46: 542-553.

(19) Suноv, K. S. \& Vоvк, C. R. 1938. Mosaic of cultivated cereals and how its communicated in nature. C. R. acad. Sc. U.R.S.S. 26, $483-486$.

(20) Tullgren, A. 1925. On dvärgstriten (Cicadula sexnotata Fall.) och năgra andra ekonomiskt viktiga stritar. Medd. 287 Centr. anst. förs. jordbr. Ent. avd. 46, 1-71. 
S E L OST U S

TUMMA VILJAKASKAS, CALLIGYPONA OBSCURELLA (BOH.), VEHNÄN VIIRUMOSAIIKKIVIRUKSEN JA KAURAN TYVIVERSOVIRUKSEN UUSI SIIRTÄJÄ

\author{
Katri IкÄheimo JA Mikko Raatikainen
}

Maatalouden tutkimuskeskus

Kasvitautien tutkimuslaitos ja Tuhoeläintutkimuslaitos, Tikkurila

Siirrostuskokein todettiin tumman viljakaskaan (Calligypona obscurella) siirtävän vehnän viirumosaiikkivirusta (wheat striate mosaic virus) ja kauran tyviversovirusta (oat sterile-dwarf virus) (taul. 1). Tumma viljakaskas siirsi kumpaakin virusta sekä toukkana että aikuisena. Kokeissa olleista kaskaista siirsivät useammat kauran tyviversovirusta kuin vehnän viirumosaiikkivirusta.

Vehnän viirumosaiikkiviruksen inkubaatioaika näyttää olevan jokseenkin yhtä pitkä tummassa viljakaskaassa (10-24 vrk) kuin viljakaskaassa (C. pellucida) (15-21 vrk). Myös kauran tyviversoviruksen inkubaatioaika näyttää olevan lähes yhtä pitkä tummassa viljakaskaassa $(10-33$ vrk $)$ kuin viljakaskaassa $(7-37$ vrk).

Tumma viljakaskas on mm. pienempi ja tummempi kuin viljakaskas (kuva 1). Sitä esiintyy kokó Suomessa.

Tumman viljakaskaan elämänkulku on saman kaltainen kuin viljakaskaan. Lajilla on yksi sukupolvi vuodessa ja se talvehtii toukkana. Aikuistuminen alkaa toukokuussa tai myöhäisinä vuosina vasta kesäkuussa. Populaatioiden pitkäsiipiset yksilöt, jotka ovat vallitsevina Etelä-Pohjanmaan heinänurmissa, vaeltavat touko-heinäkuussa etupäässä kevätviljoihin ja munivat niissä tavallisesti viljan korsiin. Toukat käyttävät ravinnokseen viljankorjuun jälkeen etenkin rikkakasveina olevia heinäkasveja ja viljaan perustettua heinää. Muokkaus tuhoaa toukat suurimmaksi osaksi.

Tumma viljakaskas on viljakaskasta keskimäärin hieman aikaisemmin, mutta huomattavasti niukemmin esiintyvä laji. Esimerkkinä mainittakoon, että viljaan perustetuissa 1. vuoden timoteinurmissa sitä oli Pohjanlahden rannikkoalueella v. 1959 keskimäärin muutama prosentti viljakaskaan määrästä. Paikoin sitä saattaa olla runsaasti, esimerkiksi eräässä Kannuksesta 5. 6. 1959 otetussa näytteessä $90 \%$ aikuisista viljakaskaista.

Tummalla viljakaskaalla saattaa olla paikoittain ja ajoittain huomattava merkitys virusten levittäjänä. Viljakaskaan runsaan esiintymisen takia näyttää kuitenkin siltä, että viljakaskas oli kauran tyviversoviruksen aiheuttaman skaurantuhon, pääasiallinen levittäjä Etelä-Pohjanmaalla v. 1956.

\title{
MAATALOUSTIETEELLINEN AIKAKAUSKIRJA TOIMITUSKUNTA
}

Erkki Kivinen, Antti Mäki, Vilho A. Pesola, Onni Pohjakallio, Ilmari Poijärvi

$$
\begin{aligned}
& \text { E. A. Jamalainen } \\
& \text { Päatoimittaja }
\end{aligned}
$$

Tikkurila. Puh. 831419 ja 831318

MAATALOUSTIETEELLISTÄ AIKAKAUSKIRJAA ilmestyy 4 vihkoa vuodessa

Käsikirjoitukset lähetetään päätoimittajalle (os. Tikkurila) tai jollekin toimitusvaliokunnan jäsenelle

SUOMEN MAATALOUSTIETEELLINEN SEURA

Puheenjohtaja:

Maat. ja metsät. toht. Matti Annila

Ulvilantie 19 a A, Helsinki

Varapuheenjohtaja:

Professori Pellervo Saarinen

Pohj. Rautatienk. 15, Helsinki
Sihteeri:

Professori V. Vainikainen

Kasarmik. 38 A 8, Helsinki

Rahastonhoitaja:

Tohtori Orvo Ring

Tikkurila

Kirjastonhoitaja :

Maisteri Majlis Tulander, Hallituskatu 3, Helsinki 